\title{
Pengaruh Perputaran Modal Kerja Perputaran Piutang, dan Perputaran Persediaan Terhadap Rentabilitas Ekonomi Perusahaan Sektor Perdagangan Eceran di Bursa Efek Indonesia
}

\author{
Anak Agung Ayu Mas Wasundari dan Ni Nyoman Suriani \\ Fakultas Ekonomi dan Bisnis, Universitas Warmadewa, Denpasar, Bali-Indonesia \\ maswulandari@gmail.com
}

How to cite (in APA style):

Wasundari, A. A. A. M., \& Suriani, N. N. (2021). Pengaruh Perputaran Modal Kerja Perputaran Piutang, dan Perputaran Persediaan Terhadap Rentabilitas Ekonomi Perusahaan Sektor Perdagangan Eceran di Bursa Efek Indonesia. Wacana Ekonomi (Jurnal Ekonomi, Bisnis dan Akuntansi). 20 (1), pp.49-54. https://doi.org/10.22225/ we.20.1.3150.49-54

\begin{abstract}
This study aims to determine the effect of working capital turnover, accounts receivable turnover, and inventory turnover simultaneously and partially on economic profitability. The research sample was 12 companies based on the purposive sampling technique. Data obtained from the website www.idx.co.id. Data analysis used multiple linear regression. The results show: (1) There is a significant influence between working capital turnover, accounts receivable turnover, and inventory turnover simultaneously on the economic profitability of retail trading companies listed on the Indonesia Stock Exchange in 2015-2018. (2) There is a significant influence between working capital turnover on the economic profitability of retail trading companies listed on the Indonesia Stock Exchange in 2015-2018. (3) There is a significant influence between the turnover of accounts receivable on the economic profitability of retail trading companies listed on the Indonesia Stock Exchange in 2015-2018. (4) There is no significant effect between inventory turnover on the economic profitability of retail trading companies listed on the Indonesia Stock Exchange in 2015-2018.
\end{abstract}

Keywords: Working Capital Turnover; Accounts Receivable Turnover; Inventory Turnover; Economic Profitability.

\begin{abstract}
Abstrak
Penelitian bertujuan untuk mengetahui pengaruh perputaran modal kerja, perputaran piutang, dan perputaran persediaan secara simultan dan parsial terhadap rentabilitas ekonomi. Sampel penelitian sebanyak 12 perusahaan berdasarkan teknik pengambilan sampel teknik purposive sampling. Data diperoleh dari situs web www.idx.co.id. Analisis data yang digunakan regresi linier berganda. Hasil penelitian menunjukkan: (1) Terdapat pengaruh signifikan antara perputaran modal kerja, perputaran piutang, dan perputaran persediaan secara simultan terhadap rentabilitas ekonomi Perusahaan sektor perdagangan eceran yang terdaftar di Bursa Efek Indonesia tahun 2015-2018. (2) Terdapat pengaruh signifikan antara perputaran modal kerja terhadap rentabilitas ekonomi Perusahaan sektor perdagangan eceran yang terdaftar di Bursa Efek Indonesia tahun 20152018. (3) Terdapat pengaruh signifikan antara perputaran piutang terhadap rentabilitas ekonomi Perusahaan sektor perdagangan eceran yang terdaftar di Bursa Efek Indonesia tahun 2015-2018. (4) Tidak terdapat pengaruh signifikan antara perputaran persediaan terhadap rentabilitas ekonomi Perusahaan sektor perdagangan eceran yang terdaftar di Bursa Efek Indonesia tahun 2015-2018.
\end{abstract}

Kata Kunci: Perputaran Modal Kerja; Perputaran Piutang; Perputaran Persediaan; Rentabilitas Ekonomi

\section{PENDAHULUAN}

Mencapai keuntungan yang optimal adalah tujuan utama setiap perusahaan. Perusahaan wajib untuk mengelola kinerja usahanya dengan baik agar dapat menjamin kelangsungan hidup usahanya dimasa yang akan datang. Laporan keuangan mencerminkan kinerja perusahaan. Dengan menganalisis laporan keuangan dimana terdiri dari pos neraca yang menggambarkan nilai aktiva dan hutang atau kewajiban perusahaan serta laporan rugi laba maka perusahaan akan dapat memperoleh gambaran posisi keuangannya.

Salah satu rasio untuk menilai keefektifan modal kerja perusahaan selama periode tertentu 
menggambarkan perputaran modal kerja, rasio menunjukan hubungan antara penjualan dengan modal kerja (Munawir 2014). Meningkatkan penjualan secara tunai ataupun kredit merupakan kegiatan penting dalam pencapaian laba. Dengan adanya penjualan kredit akan timbul investasi baru yaitu dalam bentuk piutang. Pengelolaan piutang dalam suatu perusahaan menyangkut pada perputaran piutang. Membagi antara penjualan dengan piutang rata-rata akan memperoleh gambaran efisiensi perusahaan dalam mengelola piutang.

Kecepatan digantinya persediaan barang dagang melalui penjualan menunjukan perputaran persediaan (Kasmir 2017). Makin tinggi perputaran persediaan akan menunjukkan: tingginya volume penjualan yang akan dapat mempengaruhi perolehan laba perusahaan. Sebaliknya tingkat perputaran persediaan yang lambat menyebabkan perusahaan akan beresiko mengalami kerugian. Kerugian bisa disebabkan karena biaya penyimpanan maupun biaya pemeliharaan persediaan yang terdapat digudang (Riyanto 2010). Rentabilitas menyangkut kemampuan perusahaan untuk menghasikan laba.Membandingkan laba yang berasal dari usaha dengan aset yang beroperasi didalam perusahaan akan diproleh gambaran efisiensi secara keseluruhan (Mujono, 2016).

Beberapa faktor yang diduga memiliki pengaruh terhadap rentabilitas ekonomi diantaranya perputaran modal kerja, perputran piutang dan juga perputaran persedian menunjukkan jika perputaran efektif maka perolehan labanya telah memadai dengan modal yang ada. Jadi dapat dikatakan bahwa dari perputaran tersebut dapat mempengaruhi laba perusahaan.

Penelitian dari (Mujono, 2016) menyimpulkan ada pengaruh yang positif signifikan antara perputaran modal kerja terhadap tingkat rentabilitas ekonomi. Penelitian lain oleh (Nurdalia, 2018) menunjukkan bahwa Efisiensi modal kerja berpengaruh negatif dan tidak signifikan terhadap rentabilitas ekonomis. Penelitian dilakukan oleh (Aldi, 2019) menunjukan bahwa perputaran piutang berpengaruh signifikan terhadap rentabilitas ekonomis. Sedangkan penelitian dari (Alie, 2018) menunjukkan perputaran piutang tidak berpengaruh signifikan terhadap rentabilitas ekonomi. Penelitian lainyaitu oleh (Lestari 2017) menyimpulkan perputaran persediaan tidak berpengaruh signifikan terhadap rentabilitas (ROA).

Dari penelitian-penelitian sebelumnya hasil yang diperoleh ternyata tidak konsiten, sehinga dilakukan kembali penelitian tentang faktor-faktor yang mempengaruhi rentabilitas disuatu perusahaan. Berdasarkan uraian tersebut maka penulis tertarik untuk melakukan penelitian dengan judul "Pengaruh Perputaran Modal Kerja, Perputaran Piutang, dan Perputaran Persediaan Terhadap Rentabilitas Ekonomi Pada Perusahaan Sektor Perdagangan Eceran Terdaftar di Bursa Efek Indonesia" Berdasarkan uraian latar belakang tersebut, rumusan masalah yang diangkat apakah perputaran modal kerja, perputaran piutang, dan perputaran persediaan,secara simultan dan parsial berpengaruh terhadap rentabilitas ekonomi?. Serta tujuan yang ingin dicapai adalah untuk mengetahui pengaruh perputaran modal kerja, perputaran piutang, dan perputaran persediaan, secara simultan dan parsial terhadap rentabilitas ekonomi,

\section{TINJAUAN PUSTAKA}

\section{Perputaran Modal Kerja}

Kenaikan pada rasio perputaran modal kerja dikarenakan penjualan meningkat atau lebih besar dari peningkatan modal kerja. Sebaliknya,penurunan rasio perputaran modal kerja dikarenakan penjualan menurun atau modal kerja yang meningkat (Munawir, 2014). Perputaran modal kerja dapat diukur dengan rumus berikut:

$$
=\frac{\text { Penjulan }}{\text { Modal Kerja Bersh }}
$$

\section{Perputaran Piutang}

Rasio peputaran putang digunakan untuk melihat kemampuan perusahaan dalam menagih piutangsampaikembali menjadi kas. Berikut rumus Perputaran piutang (Kasmir, 2017):

$$
=\frac{\text { Penjualan }}{\text { Piutangratarata }}
$$




\section{Perputaran Persediaan}

Makin tinggi perputran persedian menunjukkan volume penjualan tinggi dan akan dapat mempengaruhi perolehan laba perusahaan. Sebaliknya tingkat perputaranpersediaan yang terbilang lambat perusahan akan beresiko rugi (Riyanto 2010). Mengukur perputaran persediaan, dinyatakan dengan rumus sebagai berikut:

Rumus:

$$
=\frac{\text { Harga pokokpenjualan }}{\text { ratarata persediaan }}
$$

\section{Rentabilitas Ekonomi}

Rentabilitas ekonomi ialah perbandingan laba usaha dengan modal sendiri dan pinjaman yang dipergunakan untuk menghasilkan laba dalam bentuk presentase (Riyanto, 2010). Untuk menghitung rentabilitas modal sendiri dipergunakan rumus yaitu:

$\frac{\text { Laba usaha }}{\text { Total asset }} \times 100 \%$

\section{Hipotesis Penelitian}

H1: Perputaran modal kerja, Perputaran piutang dan Perputaran persediaan berpengaruh signifikan terhadap Rentabilitas ekonomis

H2: Perputaran modal kerja berpengaruh signifikan terhadap Rentabilitas ekonomis

H3: Perputaran piutang berpengaruh signifikan terhadap Rentabilitas ekonomis

H4: Perputaran persediaan berpengaruh signifikan terhadap Rentabilitas ekonomis

\section{METODE}

Tempat penelitian pada perusahaan sektor perdagangan eceran di Bursa Efek Indonesia dengan pengambilan data melaluiwww.idx.co.id. Obyek pada penelitian ini yaitu data laporan keuangan berupa laporan neraca dan laba rugi perusahaan periode 2015-2018. Populasi sebanyak 21 perusahan sektor perdagangan eceran di Bursa Efek Indonesia periode 2015-2018. Pemilihan sampel purposive sampling sehigga diperoleh sampel sebanyak 12 perusahaan. Metode pengumpulan data dengan studi dokumentasi. Berdasarkan sumber data sekunder berupa data laporan keuangan perusahaan perdagangan eceran yang diperoleh dengan cara mendownload dari situs resmi www.idx.co.id. Analisis data berupa analisis kuantitatif. Dalam analisis penulis menggunakan analisis statistik Regresi Linier Berganda dengan bantuan program SPSS. Agar dapat menggunakan analisis regresi linear berganda harus memenuhi asumsi klasik seperti uji normaltas, multikoleniaritas, heterokedastisitas serta autokrelasi. Setelah analisis regresi linear berganda selanjutnya dilakukan uji determinasi, uji F, uji-t.

\section{HASIL DAN PEMBAHASAN}

Uji Signifikansi Simultan (F-test)

Tabel 1

Hasil Uji F- test

ANOVAa

\begin{tabular}{cccccc}
\hline Model & Sum of Squares & Df & Mean & F & \multirow{2}{*}{ Sig. } \\
\hline Regression & 2902,349 & 3 & 967,450 & 12,81 & \multirow{2}{*}{$000^{\mathrm{b}}$} \\
Residual Total & 3322,236 & 44 & 75,505 & 3 & \\
\hline
\end{tabular}

\footnotetext{
a. Dependent Variable: $Y$

b. Predictors: (Constant), X3, X1, X2

Sumber : data diolah 2019
} 
Dari tabel diatas $\mathrm{F}$ hitung $>\mathrm{F}$ tabel yaitu $12,813>2,82$ dan sig $0,000<0,05$ maka Ho tidak diterima dan $\mathrm{H} 1$ diterima.Hal ini bahwa variable perputaran modal kerja, perputaran piutang serta perputaran persediaan secara simultan berpengaruh terhadap rentabilitas ekonomi pada perusahan perdagangan eceran di Bursa Efek Indonesia tahun 2015-2018.

\section{Uji statistik t-test}

Tabel 2

Hasil Uji-t

Coefficients ${ }^{\mathrm{a}}$

\begin{tabular}{cccccc}
\hline \multirow{2}{*}{ Model } & $\begin{array}{c}\text { "Unstandardized Coefficients" } \\
\text { "B" }\end{array}$ & $\begin{array}{c}\text { "Standardized Coeficients" } \\
\text { Std. Eror }\end{array}$ & tBeta" & "Sig." \\
\hline (Constant) &, 021 & 2,530 & &, 448 &, 008 \\
X1 &, 425 &, 107 &, 499 & 3,983 &, 000 \\
X2 &, 088 &, 020 &,- 142 & 4,406 &, 000 \\
X3 &,- 282 &, 230 & $-1,227$ &, 226 \\
\hline
\end{tabular}

Dependent Variabel: $\mathrm{Y}$

Sumber : diolah 2019

1) Hasil uji $t_{\text {hitung }}(3.983)>t_{\text {tabel }}(2.0153)$ dengan signifikansi sebesar $0.000<0.05$ maka H0 di tolak dan $\mathrm{H} 2$ diterima maka dapat dikatakan bahwa ada pengaruh yang signifikan secara parsial dari variabel perputaran modal kerja terhadap rentabilitas ekonomi.

2) Hasil uji nilai $t_{\text {hitung }}(4.406)>t_{\text {tabel }}(2.0153)$ dengan tingkat signifikan sebesar $0.000<0.05$ maka $\mathrm{H} 0$ di tolak dan $\mathrm{H} 3$ diterima maka dapat dikatakan bahwa ada pengaruh yang signifikan secara parsial dari variabel perputaran piutang terhadap rentabilitas ekonomi.

3)Hasil uji nilai $\mathrm{t}_{\text {hitung }}(-1.227)<\mathrm{t}_{\text {tabel }}(2.0153)$ dengan tingkat signifikan $0.226>0.05$ maka H0 di terima dan $\mathrm{H} 4$ ditolak maka dapat dikatakan bahwa tidak ada pengaruh yang signifikan secara parsial dari variabel perputaran persediaan terhadap rentabilitas ekonomi.

\section{Pembahasan}

Pengaruh Perputaran Modal Kerja, Perputaran Piutang dan Perputaran Persediaan Terhadap Rentabilitas Ekonomi

Berdasarkan uji $\mathrm{F}$ ( secara Simultan ) $\mathrm{F}_{\text {hitung }} 12,813>\mathrm{F}_{\text {tabel }} \quad 2,82$ dengan sig 0,000 " $<0,05 \mathrm{H} 0$ tidak diterima dan H1diterima. Hal ini berarti variabel perputaran modalkerja(X1),perputaran pitang (X2) dan perputaran persedian (X3) secara simultan memiliki pengaruh signifikansi terhadap rentabilitasekonomi (Y) perusahaan sektor perdagangan eceran di BEI periode 2015-2018. Hasil penelitian sejalan dengan penelitian (Lestari, 2017) bahwa perputaran piutang, perputaran persediaan dan perputaran modal kerja secara simultan berpengaruh signifikan terhadap rentabilitas pada perusahaan.

\section{Pengaruh Perputaran Modal Kerja Terhadap Rentabilitas Ekonomi}

Berdasarkan uji t,signifikansivariabel perputaran modal kerja $0,000<0,05$ dan nilai $t_{\text {hitung }}$ (3.983) lebih besar dari $t_{\text {tabel }}(2.0153)$. H2 dalam penelitian yatu peputaran modal berpengaruh signifikan terhadap rentabilitas ekonomi perusahaan sektor perdagangan eceran di Bei diterima. Dengan Perputaran modal kerja dapat melihat bagaimana penggunaan modal kerja yang ada di perusahaan apakah efektif atau tidak. Lambat atau cepanya preputaran modal kerja mempegaruhi besar jumlah modal kerja yang dinvestasikan.Semakin cepat perputaran menunjukkan semakin efektif perusahaan menggunakan modal kerjanya hal tersebut berdampak terhadap profit perusahaan. Hasil penelitian ini sama dengan hasil penelitian (Mujono, 2016) yang menyatakan bahwa perputaran modal kerja memiliki pengaruh yang signifikan terhadap tingkat rentabilitas ekonomi.

\section{Pengaruh Perputaran Piutang Terhadap Rentabilitas Ekonomi}

Berdasarkan uji $t$, signifikansi variabel perputaran piutang $0,00<005$,nilei $t_{\text {hitung }}$ (4.406) lebih besar daripada $t_{\text {tabel }}(2.0153)$. H3 yaitu peputaran piutag berpengaruh secara signifikan terhadapa retabilita ekonomi perusahan sektr perdagangan eceran di BEI diterima.Mengukur berapa lama penagihan piutang selama periode tertentu sehingga dapat kembali menjadi kas dilihat dari perputaran piutang (Kasmir, 2017). Rasio perputaran piutang memberikan gambaran dan 
pemahaman mengenai kualitas dan kesuksesan penagihan piutang. Semakin tinggi perputaran piutang berarti nilai penjualan yang tinggi, sehingga berdampak terhadap rentabilitas/profit yang diperoleh perusahaan pun juga semakin meningkat. Hasil penelitian ini sejalan dengan penelitian yang dilakukan oleh (Aldi, 2019) diketahui bahwa perputaran piutang berpengaruh signifikan terhadap rentabilitas ekonomi.

\section{Pengaruh Perputaran Persediaan Terhadap Rentabilitas Ekonomi}

Dari hasil uji t, diketahui variabel perputaran persediaan dengan signifikansi sebesar 0,226 > 0,05 dan nilai $t_{\text {hitung }}(-1.227)$ lebih kecil dari $t_{\text {tabel }}(2.0153)$. Berdasarkan hal tersebut H4 yaitu perptaran persedian bepengaruh signifikan terhadap rentabilitas ekonomi perusahaan sektor perdagangan eceran di Bei ditlak. Perputaran persediaan mengukur berapa kalijumlah barang persediaan diganti dalam periode setahun (Kasmir 2017). Makin cepat peputaran persedian maka rentabilitas ekonomi perusahan akan semakin meningkat sebaliknya semakin rendah tingkat perputaran persediaan maka rentabilitas ekonomi perusahaan juga akan rendah ini dikarenakan banyaknya persediaan yang menumpuk digudang menimbulkan kerugian bagi perusahaan disebabkan oleh adanya kerusakan, banyak memakan biaya pemeliharaan dan penyimpanan persediaan (Riyanto 2010). Hasil penelitian ini sejalan dengan penelitian yang dilakukan oleh (Lestari, 2017) yang menyatakan bahwa perputaran persediaan tidak berpengaruh signifikan terhadap rentabilitas pada perusahaan.

\section{SIMPULAN}

Berdasarkan hasil analisis data, dapat disimpulkan bahwa: Variabel perputaran modal kerja (X1), perputaran piutang(X2), dan perputaran persedian (X3) secara simultan terbukti berpengaruh signifikan terhadap rentabilita ekonomi perusahan sektor perdagangan eceran yang terdaftar di BEI tahun 2015-2018. Variabel perputaran modal kerja (X1) secara pasial terbukti bepengaruh signifikan terhadap rentabilitas ekonomi perusahan sektor perdagangan eceran di BEI tahun 2015-2018. Variabel perputaran piutang (X2) secara parsial terbukti berpengaruh signifikan terhadap rentabilitas ekonomi perusahaan sektor perdagangan eceran di BEI tahun 2015-2018. Variabel perputaran persediaan (X3) secara parsial tidak berpengaruh signifikan terhadap rentabilitas ekonomi perusahaan sektor perdagangan eceran di BEI tahun 2015-2018.

\section{DAFTAR PUSTAKA}

Aldi, N. E. (2019). Pengaruh Perputaran Piutang Dan Persediaan Terhadap Rentabilitas Pada Perusahaan Sub Sektor Rokok Yang Terdaftar Di Bei. Medan: Fakultas Ekonomi Dan Bisnis Universitas Medan Area. Retrieved from http://repository.uma.ac.id/bitstream/123456789/10831/1/158320139\%20-\% 20Nur\%20Eza\%20Aldi\%20-\%20Fulltext.pdf

Alie, M. S., \& Kurniati, N. S. (2018). Pengaruh Perputaran Kas, Perputaran Piutang, Perputaran Persediaan Terhadap Rentabilitas Ekonomi Pada Perusahaan Otomotif Yang Go Public. Jurnal Ekonomi, 20(3). Retrieved from https://ejournal.borobudur.ac.id/index.php/1/article/view/481

Runtunuwu, C. C., Alexander, S. W., \& Wokas, H. R. N. (2017). Pengaruh Perputaran Persediaan, Perputaran Kas Dan Persediaan Piutang Rentabilitas Ekonomis (Studi Pada Perusahaan Manufaktur Sub Sektor Food And Beverages Yang Terdaftar Di Bursa Efek Indonesia Tahun 2012-2016). Jurnal Riset Akuntansi Going Concern 12(2), 703-716. Retrieved from https://doi.org/10.32400/ gc.12.2.18033.2017

Budiasa, N., Herawati, N. T., \& Musmini, L. S. (2014). Pengaruh Perputaran Modal Kerja Terhadap Rentabilitas Ekonomi Pada Perusahaan Manufaktur Yang Terdaftar Pada Bei Periode 2010 - 2012. e -Journal S1 Ak Universitas Pendidikan Ganesha, 2(1). Retrieved from http://dx.doi.org/10.23887/ jimat.v2i1.4356

Harahap, S. S. (2013). Analisa Kritis Atas Laporan Keuangan . Jakarta: Rajawali Pers.

Kasmir. (2013). Analisis Laporan Keuangan. Jakarta: PT Raja Grafindo Persada. 
Wacana Ekonomi (Jurnal Ekonomi Bisnis dan Akuntansi), 20 (1) 2021, 54

Pengaruh Perputaran Modal Kerja Perputaran Piutang, dan Perputaran Persediaan Terhadap Rentabilitas Ekonomi Perusahaan Sektor Perdagangan Eceran di Bursa Efek Indonesia

Kasmir. (2017). Analisis Laporan Keuangan. Jakarta: PT Raja Grafindo Persada.

Lestari, A. (2017). Pengaruh Perputaran Kas, Piutang, Persediaan, Dan Modal Kerja Terhadap Rentabilitas Ekonomi Pada Perusahaan Manufaktur Yang Terdaftar Di Bei Tahun 2011-2014. BISECER (Business Economic Entrepreneurship). 1(1). Retrieved from https://garuda.ristekbrin.go.id/ documents/detail/1191548

Mujiono, A. (2016). Pengaruh Perputaran Modal Kerja Terhadap Rentabilitas Ekonomi Koperasi Wibawa Bapppeda Tahun 2006-2015. Skripsi Politeknik Piksi Ganesha, Bandung

Munawir, S. (2014). Analisa Laporan Keuangan. Edisi Keempat. Yogyakarta: Liberty

Nurdalia, Kadir, A., \& Tikollah R. (2018). Pengaruh Efisiensi Modal Kerja Terhadap Rentabilitas Ekonomis Pada Perusahaan Food And Beverages Yang Terdaftar Di Bursa Efek Indonesia. Universitas Negeri Makassar. Retrieved from http://eprints.unm.ac.id/11635/

Riyanto, B. (2010). Dasar-Dasar Pembelanjaan Perusahaan. Yogyakarta: BPFE.

Rusanti, M. (2018). Analisis Perputaran Piutang Terhadap Rentabilitas Pada Pt Ace Hardware Indonesia Tbk. Periode Tahun 2010-2017. Tugas Akhir, Samarinda.

Sartono, A. (2010). Manajemen Keuangan Teori Dan Aplikasi. Yogyakarta: BPFE.

Sawir, A. (2005). Analisis Kinerja Keuangan Dan Perencanaan Keuangan. Jakarta : Pt Gramedia Pustaka Utama. 